\title{
STRATEGIC COMPETITIVENESS AND PERFORMANCE ADVANTAGE OF INDONESIAN MINING COMPANY
}

\author{
Abdul Rauf \\ Ph.D scholar, Post Graduate School of Economics \\ Hasanuddin University \\ South Sulawesi, Indonesia \\ Abd. Rahman Kadir \\ Professor of Economics, Post Graduate School of Economics \\ Hasanuddin University \\ South Sulawesi, Indonesia \\ Muhammad Yunus Amar \\ Ph.D of Economics, Post Graduate School of Economics \\ Hasanuddin University \\ South Sulawesi, Indonesia \\ Maat Pono \\ Ph.D of Economics, Post Graduate School of Economics \\ Hasanuddin University \\ South Sulawesi, Indonesia \\ DOI: 10.31364/SCIRJ/v6.i12.2018.P1218594 \\ http://dx.doi.org/10.31364/SCIRJ/v6.i12.2018.P1218594
}

\begin{abstract}
This study aims (i) to find the main source of sustainable competitive advantage in mining companies in Indonesia; (ii) to find out the capability of the organization which is a source of sustainable competitive advantage in mining companies in Indonesia; and (iii) to analyze the relationship between organizational capabilities to the sustainable competitive advantage of mining companies in Indonesia and their relationship with company performance. This research was designed as a quantitative study using survey methods on mineral and coal mining companies in Indonesia. The study population is managers in coal and mineral mining companies in Indonesia. The type of data in this study consists of primary data and secondary data. Primary data is obtained from the results of the questionnaire response to each respondent. Secondary data are company annual reports, Indonesia Stock Exchange reports and various other publication reports. The main data collection method uses a closed questionnaire. The analysis technique uses Structural Equation Modeling. The results of this study indicate that there is no positive relationship between the company's distinctive advantages and sustainable competitive advantage. Core competencies have no effect on sustainable competitive advantage. Typical organizational capital does not affect sustainable competitive advantage. The company's unique resources have a significant and positive effect on sustainable competitive advantage. Environmental strategic factors have no effect on sustainable competitive advantage. Sustainable competitive advantage has a positive and significant effect on company performance.
\end{abstract}

Index Terms - superiority, core competencies, organizational capital, company resources, and environmental strategic factors

\section{INTRODUCTION}

The mineral mining sector has contributed significantly to national GDP. Historical data from 1880-2007 shows that the average contribution of the mineral and coal sector to national GDP is $3.44 \%$ with a minimum value of $1.28 \%$ in 1984 and a maximum of $6.29 \%$ in 1900 . Moreover, this contribution tends to stable. Mineral and coal contributions to GDP are increasingly consistent from year to year. In fact, increasingly into the present, mining contributions have begun to follow the national GDP 
growth rate. This is different from the contribution of oil and gas which actually decreases until finally, the rate of growth contributes lower than the national GDP growth rate.

State revenues from the mineral sector from year to year continue to increase, along with the declining income from the oil and gas sector. Even though it is still below the oil and gas sector, the drastic increase that will occur will bring the mining sector to greater income and ultimately be able to defeat the oil and gas sector. When 2008-2014 data was added, revenue from the mineral sector had exceeded the revenue from the oil and gas sector since 2012. This year, the oil and gas sector contributed 3.50\% to GDP while the mineral and gas sector contributed 3.87\%. Since then, the contribution of the mining sector has been increasing, while the contribution of the oil and gas sector has diminished.

There is a theory of productive structure and theories of co-factors and changes in institutions (Willebald et al, 2015: 2). Productive structure theory sees that countries with large natural wealth tend to have homogeneous production structures and this homogeneity lies in extractive industries rather than service and production industries. Because of this homogeneity, there is very little capability for other fields that should function when extractive markets are problematic.

In the Resources Based View Theory, company-owned resources are the main factors that determine a company's performance. This can produce a sustainable competitive advantage of the company. According to Barney (1991), Concept Resources includes all assets, capabilities, organizational processes, attributes of the company, information, knowledge and so on, which are controlled by the company that makes it capable of compiling and implementing strategies to improve efficiency and effectiveness (Barney, 1991). Conversely, in Competitive Forces Advantages (CFA) introduced by Porter (1980), the source of sustainable excellence lies in the external environment of a company. In the CFA, the industrial structure has a strong influence on the rules of competition. So that the strategic issue of a company is to pay attention to the position of its competitiveness in the industry.

The theory of RBV and CFA can support each other by seeing that the competitive advantage of a company is influenced by both internal and external factors. Internal factors in the form of resources help companies to design and implement strategies that will lead to sustainable competitive advantage and superior performance (Leonidou et al, 2013). Sustainable competitive advantage comes from the CFA theory because it was first put forward by Porter (1980).

By using environmental strategic factors (Shirokova et al, 2016: 707) as variables other than RBV variables, such as core competencies, organizational capital, distinctive advantages, and company-specific resources, the integration between RBV and CFA in supporting sustainable competitive advantage and performance company can be tested. This study aims (i) to find the main source of sustainable competitive advantage in mining companies in Indonesia; (ii) to find out the capability of the organization which is a source of sustainable competitive advantage in mining companies in Indonesia; and (iii) to analyze the relationship between organizational capabilities to the sustainable competitive advantage of mining companies in Indonesia and their relationship with company performance.

\section{LITERATURE REVIEW}

\subsection{Theory of Resource Based View (RBV)}

Contemporary management theory now relies on two different paradigms, namely the placement paradigm of Porter and the resource-based paradigm (RBV) of Penrose (Kazozcu, 2011). The placement paradigm argues that the competitive advantage of a company lies in adjusting to the environment. The company's strategy orientation is to look at the external environment in the form of industrial attractiveness and the relative position of companies in the industry. Resources that can be used to achieve competitive advantage according to the RBV are resources that fulfill four criteria: valuable, rare, cannot be imitated perfectly, and cannot be replaced (Leonidou et al, 2013).

The RBV believes that resources that are the source of competitive advantage must be confined within the company's boundaries. As a result, the view arises that the RBV cannot work in high-speed markets because such markets will require companies to build new resource configurations and move to fresh competitive positions using the logic of change (Hugh et al, 2017). Strategies are formed by exploiting these resources as strengths, avoiding internal weaknesses, and responding to opportunities in the environment and neutralizing threats from the environment (Leonidou et al, 2013).

\subsection{Company performance}

Company performance according to Katragadda (2013) is "the effectiveness of a company in achieving the output it wants to achieve within a certain target time". Smith \& Reece (1999: 153 in Khalid, 2015) defines corporate performance as "operational capabilities to satisfy the desires of the owner-owner's major shareholders." Meanwhile, Drucker (2002 in Khalid, 2015) mentions the company's performance as "the clear attainment or outcome level that is sometimes used to measure positive results". Edmunds (1984 in Khalid, 2015) defines a company's performance as" the output of management decisions to achieve certain goals in an effective and efficient way".

In the beginning, the concept of corporate performance was only viewed solely in the context of financial gain. However, in its development, this indicator is insufficient. This is because profits do not provide a comprehensive picture of the total value created by the company (Harrison \& John, 2013). The balanced scorecard is a strategic management tool and widely accepted measurements. 
The balanced scorecard is often used as a strategic tool and as a tool to encourage the professionalization of a company (Kaplan \& Norton, 2008).

\section{RESEARCH METHODS}

This research was designed as a quantitative study using survey methods on mineral and coal mining companies in Indonesia. This research was conducted to test and analyze the factors that influence the performance of the company by placing distinctive advantages of the company; core competencies; company-specific organizational capital; typical company resources; and environmental strategic factors as exogeneous variables and sustainable competitive advantage as intervening variables. The research location is coal and mineral mining companies in Indonesia. The research population is Managers in coal and mineral mining companies in Indonesia. The number of samples in this study were 101 companies in Indonesia. The analysis technique uses Structural Equation Modeling (SEM) analysis

\section{RESULTS AND DISCUSSION}

\section{Characteristics of Research Respondents}

Respondent characteristics of the company's products in this study. From the results of the table, it can be seen that coal companies account for 44 companies or $43.6 \%$; and a sample of mineral companies of 57 companies or $56.4 \%$. This shows that the sample of respondents in this study was mostly represented by mineral companies compared to coal companies. Complete data about the characteristics of respondents are presented in the following table

Table 1 Respondent Composition by Location

\begin{tabular}{lcccc}
\hline & Frequency & Percent & Valid Percent & Cumulative Percent \\
\hline Aceh & 1 & 1,0 & 1,0 & 1,0 \\
Babel & 1 & 1,0 & 1,0 & 2,0 \\
Bali & 1 & 1,0 & 1,0 & 3,0 \\
Bengkulu & 1 & 1,0 & 1,0 & 5,0 \\
DIY & 1 & 1,0 & 1,0 & 5,9 \\
DKI Jakarta & 1 & 1,0 & 1,0 & 6,9 \\
Gorontalo & 1 & 1,0 & 1,0 & 10,9 \\
Jawa Barat & 4 & 4,0 & 4,0 & 11,9 \\
Jawa Tengah & 1 & 1,0 & 1,0 & 12,9 \\
Jawa Timur & 1 & 1,0 & 1,0 & 20,8 \\
Kalsel & 8 & 7,9 & 7,9 & 22,8 \\
Kalteng & 2 & 2,0 & 2,0 & 38,6 \\
Kaltim & 16 & 15,8 & 15,8 & 39,6 \\
Kalut & 1 & 1,0 & 1,0 & 40,6 \\
Kepulauan Riau & 1 & 1,0 & 41,6 \\
Lampung & 1 & 1,0 & 1,0 & 42,6 \\
Maluku & 1 & 1,0 & 1,0 & 47,5 \\
Maluku Utara & 5 & 5,0 & 5,0 & 48,5 \\
NTB & 1 & 1,0 & 49,5 \\
NTT & 1 & 1,0 & 1,0 & 53,5 \\
Papua & 4 & 4,0 & 4,0 & 55,4 \\
Papua Barat & 2 & 2,0 & 2,0 & 80,2 \\
Sulsel & 25 & 24,8 & 24,8 & 85,1 \\
Sulteng & 5 & 5,0 & 5,0 & 92,1 \\
Sultra & 7 & 6,9 & 6,9 & 100,0 \\
Sumsel & 8 & 7,9 & 7,9 & \\
Total & $\mathbf{1 0 1}$ & $\mathbf{1 0 0 , 0}$ & $\mathbf{1 0 0 , 0}$ & \\
\hline & & & & \\
& & & & \\
\end{tabular}

Respondent characteristics from the location in this study are shown in Table 1. From the results of the table, it can be seen that companies from East Kalimantan (Kaltim) number 16 or $15.8 \%$ of the total sample percentages. Meanwhile, there were 25 companies in South Sulawesi (South Sulawesi) or 24.8\%. Sixty (60) other companies are spread in 24 provinces with a number per 
province under 10 companies. This shows that the sample of respondents in this study was more represented by samples from East Kalimantan and South Sulawesi than from other provinces.

\section{Test Reliability}

The reliability of the measurement results was tested using the Cronbach Alpha value. A construct is said to be reliable if it has a Cronbach Alpha value> 0.7 .

Table 2 Test Reliability

\begin{tabular}{llcl}
\hline No & Variable & Cronbach Alpha & Information \\
\hline 1 & Typical Advantages of the Company & 0.917 & Reliable \\
2 & Core Competence & 0.879 & Reliable \\
3 & Typical Company Organizational Capital & 0.696 & Not reliable \\
4 & Typical Company Resources & 0.721 & Reliable \\
5 & Strategic Environment Factors & 0.914 & Reliable \\
6 & Sustainable Competitive Advantages & 0.943 & Reliable \\
7 & Company performance & 0.874 & Reliable \\
\hline
\end{tabular}

From the results of table 2 below, it can be concluded that the constructs of each variable in this study are reliable, except the Typical Organizational Capital variable of the company. The most reliable variable is Sustainable Competitive Advantage with a reliability of 0.943>0.700; while the lowest reliability variable is the Typical Corporate Capital with a value of Cronbach Alpha 0.696 $<0.700$.

\section{SEM Test Full Model and Hypothesis Test}

The test results of the full structural model model of the relationship between eco-gene variables and endogenous variables are shown in Figure 1. In this model, exogenous variables are distinctive company excellence (KKP), core competency (KI), company-specific organizational capital (MOKP), resources company-specific (SDKP), and environmental strategic factors (VSL), while endogenous variables are sustainable competitive advantage (KBB) and company performance (KP). 


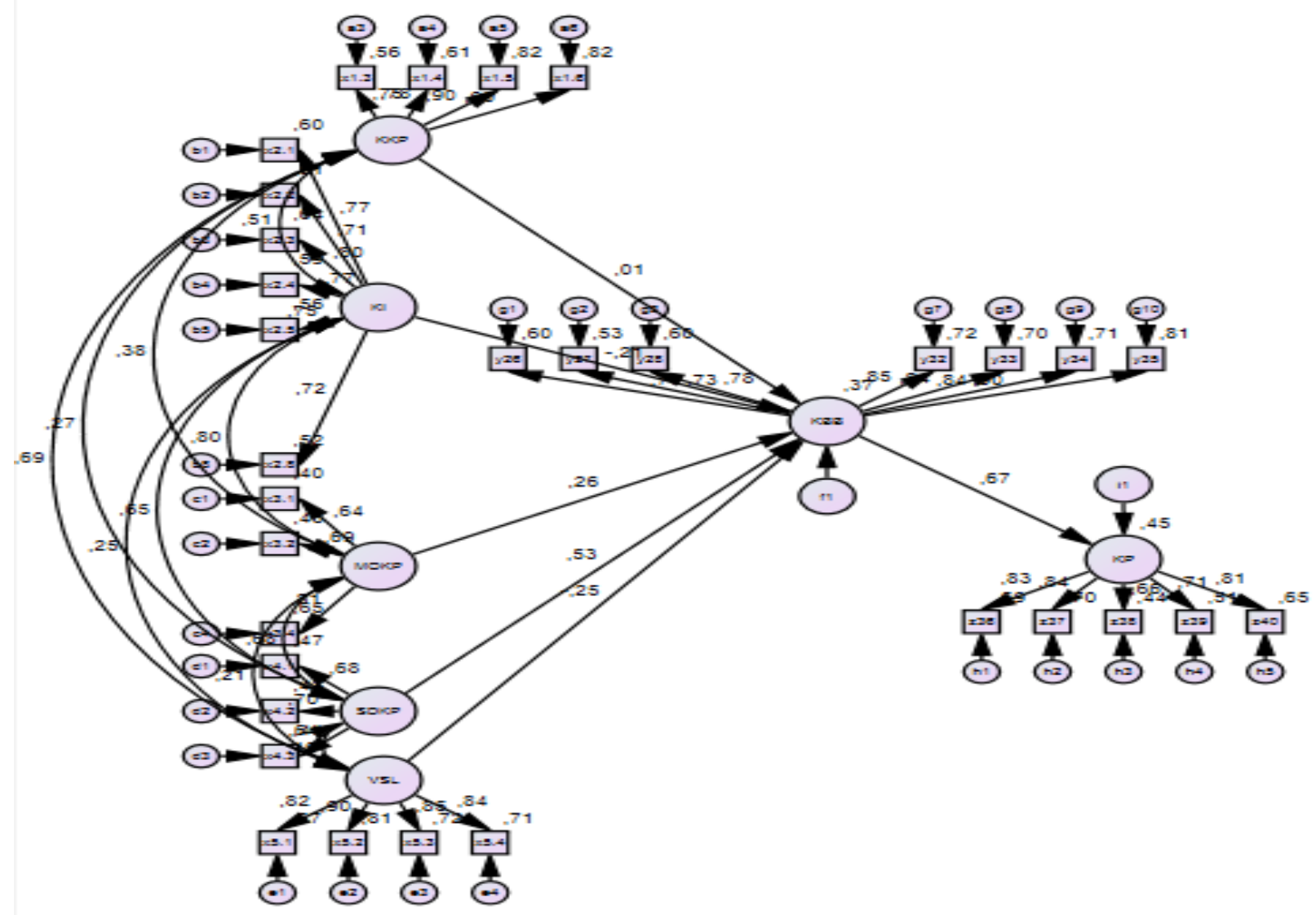

Figure 1. AMOS results in this study

The compatibility parameters of the model above are reported in Table 3 below. There are only two criteria models that indicate the existence of a model fit or compatibility between the data and the model, namely CMIN / DF and RMSEA. Other criteria do not meet the cut-off value criteria. This requires that the model be improved by gradual respecification.

Table 3. Evaluation of Criteria for the Goodness of Fit Full Model

\begin{tabular}{|l|c|c|l|}
\hline Goodness of Fit Indices & Cut-off Value & Model Results & Conclusion \\
\hline$\chi^{2}($ Chi square $)$ & $\leq 5.991$ & 709.98 & Poorly \\
\hline Probability & $\geq 0.05$ & 0.000 & Poorly \\
\hline CMIN/DF & $\leq 2.00$ & 1.58 & Good \\
\hline GFI & $\geq 0.90$ & 0.732 & Poorly \\
\hline AGFI & $\geq 0.90$ & 0.684 & Poorly \\
\hline TLI & $\geq 0.95$ & 0.866 & Poorly \\
\hline CFI & $\geq 0.95$ & 0.879 & Poorly \\
\hline RMSEA & $\leq 0.08$ & 0.077 & Good \\
\hline
\end{tabular}

The results of model respecification are shown in Figure 2. In this picture, all latent variables have been reduced to a minimum so that each of them only leaves the two most representative indicators. This is done because the model continuously produces a low model match index. A latent variable cannot be represented by only one indicator because it shows that there is no measurement error at all which is certainly impossible except for exact indicators such as height, weight, age, sex, and the like. The value of two indicators for one variable can still represent variables because the two indicators used have the largest loading factor which can be very close to 1 , which means that it represents the latent variable that you want to measure. 


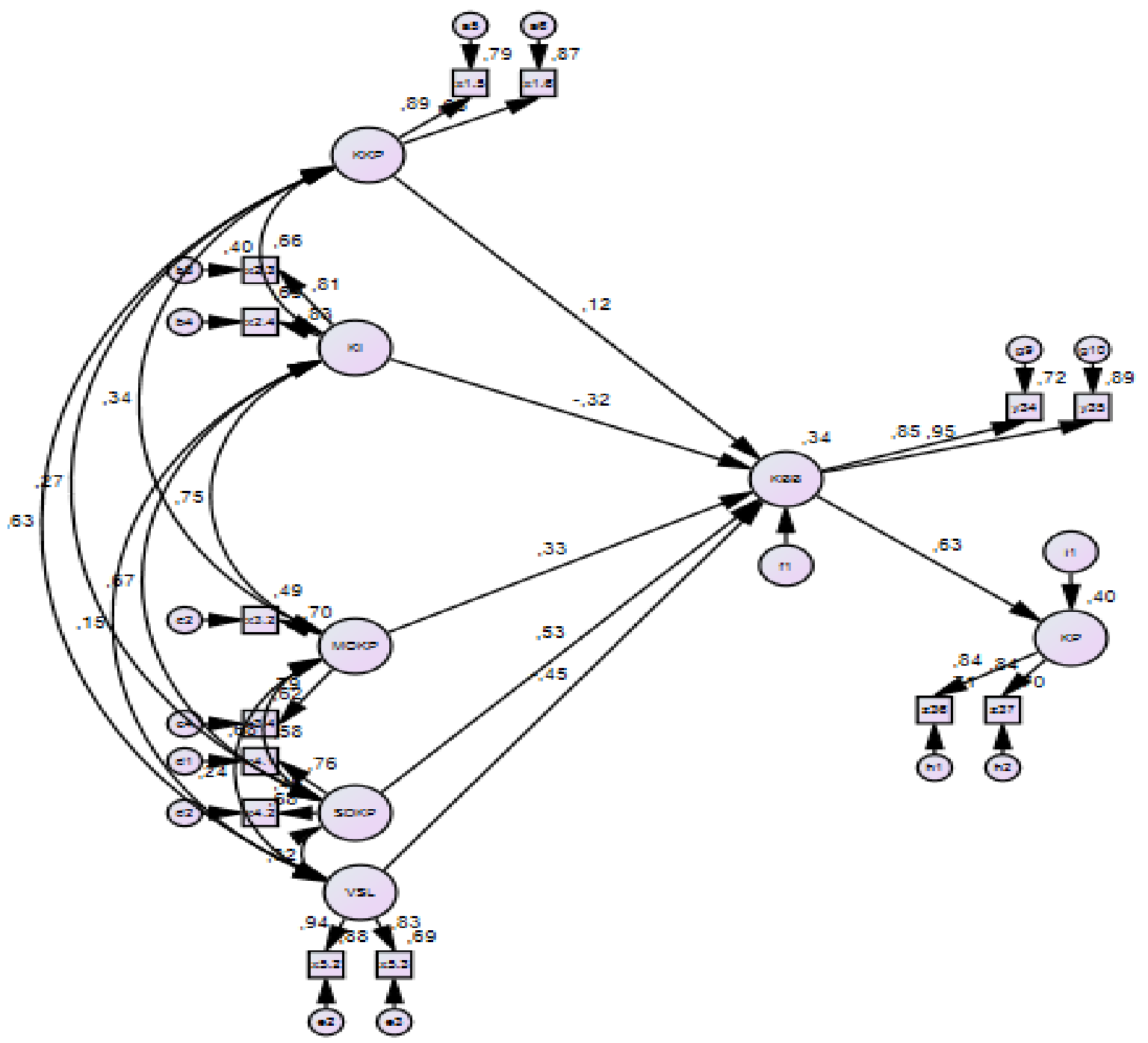

Figure 2. AMOS results of this study (Respecification 1)

The compatibility criteria of the respecification model are relatively worse with one criterion, namely RMSEA, which no longer meets the required limits. The RMSEA value obtained is equal to 0.090 which is greater than the maximum limit of 0.080 , whereas before the respec- tion the RMSEA value was still at 0.077 . Therefore, the respecification model was rejected and the initial SEM model was accepted. This model can be even better if the relationships and variables that are not significant are removed. However, first it needs to be seen what relationships are significant in this model.

Table 4. Evaluation of Criteria for Goodness of Fit Full Model (Respecification 1)

\begin{tabular}{lrcl}
\hline Goodness of Fit Indices & Cut-off Value & Model Results & Conclusion \\
\hline$\chi^{2}($ Chi square $)$ & $\leq 5.991$ & 110.31 & Poorly \\
Probabilitas & $\geq 0.05$ & 0.000 & Poorly \\
CMIN/DF & $\leq 2.00$ & 1.81 & Good \\
GFI & $\geq 0.90$ & 0.871 & Poorly \\
AGFI & $\geq 0.90$ & 0.778 & Poorly \\
TLI & $\geq 0.95$ & 0.898 & Poorly \\
CFI & $\geq 0.95$ & 0.931 & Poorly \\
RMSEA & $\leq 0.08$ & 0.090 & Poorly \\
\hline
\end{tabular}

From the accepted model, namely the initial model (Figure 1), it is calculated that the magnitude of the influence and contribution given by company-specific latent variables, core competencies, company-specific organizational capital, company- 
specific resources, and environmental strategic factors towards sustainable competitive advantage is equal to R2 $=0.369$ or $36.9 \%$, which means the diversity of data on sustainable competitive advantage that can be explained by distinctive corporate advantages, core competencies, typical corporate capital, company-specific resources, and environmental strategic factors of 36.9\%. Meanwhile, the magnitude of the influence or contribution provided by sustainable competitive advantage on organizational performance is $\mathrm{R} 2=$ 0.449 or $44.9 \%$, which means that the diversity of organizational performance data that can be explained by sustainable competitive advantage is $44.9 \%$ of all data.

Table 5 shows the regression coefficient values (regression weight estimate) and critical ratio (t count). The hypothesis will be accepted if the $\mathrm{p}$ value is $\leq 0.05$. The model estimation results are as follows.

Table 5. Hypothesis testing

\begin{tabular}{|l|l|l|l|l|r|r|r|l|}
\hline \multicolumn{2}{|l|}{ Variabel } & $\lambda$ & \multicolumn{1}{l|}{ S.E } & \multicolumn{1}{l|}{ C.R } & p-value & Conclusion & H & Conclusion \\
\hline KKP & KBB & 0.01 & 0.14 & 0.03 & 0.98 & Not Sig. & H1 & Rejected \\
\hline KI & KBB & -0.21 & 0.29 & -0.85 & 0.39 & Not Sig. & H2 & Rejected \\
\hline MOKP & KBB & 0.26 & 0.26 & 1.06 & 0.29 & Not Sig. & H3 & Rejected \\
\hline SDKP & KBB & 0.53 & 0.29 & 2.60 & 0.01 & Sig. & H4 & Received \\
\hline VSL & KBB & -0.25 & 0.12 & -1.65 & 0.10 & Not Sig & H5 & Rejected \\
\hline KBB & KP & 0.67 & 0.10 & 5.94 & $* * *$ & Sig & H6 & Received \\
\hline
\end{tabular}

Based on the value of the critical ratio of 0.03 and the value of $p$ value as much as $0.98(>0.05)$ and the loading factor of 0.01 , it can be concluded that with the increase in distinctive company advantages, there will be no impact on increasing competitive advantage keep going. Statistical values indicate that there is no significant influence between the company's distinctive advantages over sustainable competitive advantage, assuming other factors that influence the size of sustainable competitive advantage are considered constant. From these results, then Hypothesis 1 which states the existence of a positive and significant relationship between the distinctive advantages of a company and sustainable competitive advantage is rejected.

Based on the value of the critical ratio of -0.85 and the value of $p$ value as much as $0.39(>0.05)$ and the loading factor of 0.21 , it can be concluded that with the increase in core competencies, there will be no impact on increasing excellence sustainable competition. Statistical values show no significant influence between core competencies on sustainable competitive advantage, assuming other factors that influence the size of continuing competitive advantage are considered constant. From these results, Hypothesis 2 which states that there is a positive and significant relationship between core competencies and sustainable competitive advantage is rejected.

Based on the value of the critical ratio of 0.29 and the value of $p$ value as much as $0.29(>0.05)$ and the loading factor of 0.26 , it can be concluded that with the increase in organizational capital typical of the company, there will be no impact on increasing sustainable competitive advantage. Statistical values show the insignificant influence of typical corporate capital on sustainable competitive advantage, assuming other factors that influence the size of sustainable competitive advantage are considered constant. From these results, Hypothesis 3 which states the existence of a positive and significant relationship between the typical organizational capital of a company and sustainable competitive advantage is rejected.

Based on the value of the critical ratio of 2.60 and the value of $p$ value as large as $0.01(<0.05)$ and the loading factor of 0.53 , it can be concluded that with the increase in typical company resources, there will be an impact on increasing competitive advantage sustainable. Statistical values indicate a significant influence between company-specific resources on sustainable competitive advantage, assuming other factors that influence the size of sustainable competitive advantage are considered constant. From these results, Hypothesis 4 which states the existence of a positive and significant relationship between the company's unique resources and sustainable competitive advantage is accepted.

Based on the critical value ratio of -1.65 and the value of $p$ value is $0.10(>0.05)$ and the loading factor is -0.25 , it can be concluded that with the increase in environmental strategic factors, there will be no impact on the increase sustainable competitive advantage. Statistical values show there is no positive and significant influence between environmental strategic factors on sustainable competitive advantage, assuming other factors that influence the size of sustainable competitive advantage are considered constant. From these results, Hypothesis 5 which states that there is a positive and significant relationship between environmental strategic factors and sustainable competitive advantage is rejected.

Based on the value of the critical ratio of 5.94 and the value of $p$ value as much as $0,000(<0.05)$ and the loading factor of 0.67 , it can be concluded that with the increase in sustainable competitive advantage, there will be an impact on improving the performance of the company. Statistical values show a positive and significant influence between sustainable competitive advantage on company performance, assuming other factors that influence the size of the company's performance are considered constant. From these results, then Hypothesis 6 which states the existence of a positive and significant relationship between sustainable competitive advantage and company performance is accepted. 


\section{CONCLUDING REMARKS}

There is no positive relationship between the company's distinctive advantages and sustainable competitive advantage. This can be caused by the distinctive advantages that are very temporary so that they are only able to provide a short competitive advantage. Another reason that can explain this finding is due to illegal mining practices that damage the market for large companies. Core competencies have no effect on sustainable competitive advantage. This finding is explained by the specific character of core competencies so that the core competencies of each company have different effects on sustainable competitive advantage. In addition, this can also occur because core competencies only give a short and unsustainable competitive advantage.

Typical organizational capital does not affect sustainable competitive advantage. This is caused by typical organizational capital that is so fluid that it can be easily imitated by competing companies in the mining industry. The company's unique resources have a significant and positive effect on sustainable competitive advantage. These results are in accordance with the RBV resourcebased theoretical proposition which confirms that unique and inimitable resources will give the company a sustainable competitive advantage.

Environmental strategic factors have no effect on sustainable competitive advantage. This is due to the very high variation in environmental strategic factors experienced by mining companies even though they work in the same industry. This finding rejects the CFA theory while providing strong support for the RBV theory. Sustainable competitive advantage has a positive and significant effect on company performance. These results have indeed been pre-predicted by both the CFA and RBV because superior performance is a logical implication of the existence of continuous competitive advantage.

\section{REFERENCES}

[1] Barney, J. (1991). Firm resources and sustained competitive advantage. Journal of management, 17(1), 99-120.

[2] Harrison, J. S., \& John, C. H. S. (2013). Foundations in strategic management. Cengage Learning.

[3] Hugh, J. H., Wang, Y., \& Naim, M. (2017). Reconceptualization of information technology flexibility for supply chain management: An empirical study. International Journal of Production Economics, 187, 196-215.

[4] Kaplan, R.S., \& Norton, D.P (2008).The Execution Premium.Harvard: Harvard Business Press

[5] Katragadda, R. (2013). Corporate governance and firm performance: a theoretical review. International Journal, 1(7).

[6] Kazozcu, S. B. (2011). Role of strategic flexibility in the choice of turnaround strategies: A resource based approach. ProcediaSocial and Behavioral Sciences, 24, 444-459.

[7] Khalid, B. (2015). Entrepreneurial behavior, social and economic institutions and performance of micro and small livestock enterprises in north eastern region, Kenya (Doctoral dissertation, University of Nairobi).

[8] Leonidou, L. C., Leonidou, C. N., Fotiadis, T. A., \& Zeriti, A. (2013). Resources and capabilities as drivers of hotel environmental marketing strategy: Implications for competitive advantage and performance. Tourism Management, 35, 94-110.

[9] Porter, M. E. (1980). Competitive strategy: Techniques for analyzing industries and competitors. Simon and Schuster.

[10] Sachs, J. D., \& Warner, A. M. (2001). The curse of natural resources. European economic review, 45(4), 827-838.

[11] Shapiro, D., Russell, B. I., \& Pitt, L. F. (2007). Strategic heterogeneity in the global mining industry. Transnational Corporations, 16(3), 1.

[12] Shirokova, G., Bogatyreva, K., Beliaeva, T., \& Puffer, S. (2016). Entrepreneurial orientation and firm performance in different environmental settings: Contingency and configurational approaches. Journal of Small Business and Enterprise Development, 23(3), 703-727.

[13] Willebald, H., Badia-Miro, M., \& Pinilla, V. (2015) Introduction: Natural resources and economic development - what can we learn from history? In Barbier, Edward B (Eds). Natural resources and economic development. Cambridge University Press, 125. 